УДК $351.88:: 327.7$

DOI https://doi.org/10.51547/ppp.dp.ua/2021.6.3

\title{
Юхно Ірина Валеріївна,
}

аспірантка кафедри державного управління

і місцевого самоврядування

Навчально-наукового інституту державного управління

Національного технічного університету

«Дніпровська політехніка»

\section{СТАБІЛЬНІСТЬ ПУБЛІЧНО-УПРАВЛІНСЬКОЇ ДІЯЛЬНОСТІ: КОНСТИТУЦЙНО-ПРАВОВИЙ ЗМІСТ}

\section{STABILITY OF PUBLIC ADMINISTRATION: CONSTITUTIONAL AND LEGAL CONTENT}

У статті досліджено поняття стабільності публічно-управлінської діяльності з позицій конституціийно-правового змісту. Проаналізовано напрями конституційної реформи, визначено особливості суб 'єктності органів влади у процесі реформ. У статті обтрунтовано розвиток суспільних відносин в Украӥні в умовах конституційного реформування, розкрито інституціональні й теоретичні засади трансформаційного процесу в публічному управлінні. Розвинуто авторську класифікацію особливостей конституційного регулювання окремих складників публічного управління в Украӥні, на цій основі запропоновано авторський підхід до розвитку нових форм публічно-управлінської діяльності. Проаналізовано особливості конституиійних змін, реалізованих у 2014-2021 роках в Украӥні, з позицій суспільних потреб.

Розроблено рекомендації щзодо удосконалення засад нормативно-правового, організаційного та інституціонального забезпечення реалізації демократичних основ публічно-управлінської діяльності в умовах трансформації українського суспільства.

Визначено критерії стабільності публічно-управлінської діяльності (ПУД) в умовах конституційного реформування. Обтрунтовано залежність результатів конституційного реформування від напрацฺювання програмних цุілей реформування, наявності відповідного «конституційного традичіоналізму», наявності політичного сприйняття реформ. Стабільність ПУД запропоновано визначити як: абсолютно стабільну (гранично стабільну систему); абсолютно стабільну систему публічного управління (або гранично стабільну систему); умовно стабільну систему публічного управління; нестабільну систему публічного управління. Доведено, щцо саме стабільність управління забезпечує можливість досягнення програмованого результату.

Обтрунтовано концептуальну модель транзитивної моделі сталого розвитку публічного управління, в основі якої закріплено конщепт стабільності публічно-управлінської діяльності. Доведено, щяо консервативна по суті модель публічного управління в прочесі реформ має показувати стабільний стан функціонування, щчо може бути визначено на основі критеріального аналізу складників реформ.

Ключові слова: держава, державне управління, європейські иүінності, Конституція Украӥни, конституційні зміни, конституиійна реформа, правова держава.

The article examines the concept of stability of public administration from the standpoint of constitutional and legal content. The directions of the constitutional reform are analyzed, the peculiarities of the subjectivity of the authorities in the process of reforms are determined. The article substantiates the development of public relations in Ukraine in the conditions of constitutional reform, reveals the institutional and theoretical foundations of the transformation process in public administration. The author's classification of features of constitutional regulation of separate components of public administration in Ukraine is developed, on this basis the author's approach concerning development of new forms of public administration activity is offered. The peculiarities of the constitutional changes implemented in 2014-2021 in Ukraine from the standpoint of social needs are analyzed.

Recommendations for improving the principles of legal, organizational and institutional support for the implementation of democratic foundations of public administration in the transformation of Ukrainian society have been developed.

The criteria of stability of public administration activity (PUA) in the conditions of constitutional reform are determined. The dependence of the results of constitutional reform on the development of program goals of reform, the presence of appropriate "constitutional traditionalism", the presence of political perception of reforms is substantiated. It is proposed to define the stability of PUA as: absolutely stable (extremely stable system); absolutely stable system of public administration (or extremely stable system); conditionally stable system of public administration; unstable system of public administration. It is proved that the stability of management provides the ability to achieve a programmed result. 
The conceptual model of the transitive model of sustainable development of public administration is substantiated, on the basis of which the concept of stability of public administration activity is fixed. It is proved that the essentially conservative model of public administration in the process of reforms should show a stable state of functioning, which can be determined on the basis of criterion analysis of the components of reforms.

Key words: Constitution of Ukraine, constitutional changes, constitutional reform, European values, legal power, power, public administration activity, state administration.

Постановка проблеми. Сучасні дослідження конституційного реформування у межах системи публічного управління завжди зумовлені показниками самої системи, до яких відносять, серед іншого, сталість, стабільність, ефективність, прогнозованість, відкритість тощо. Разом із тим проблема стабільності публічно-управлінської діяльності детермінована станом системи публічного управління, відсутністю нормативного регулювання терміна «публічно-управлінська діяльність». Вважаємо, що системний підхід є базовим методологічним концептом, спрямованим на визначення характеру впливу конституційних змін на стан та перспективи розвитку публічного управління в Україні на основі положень Конституції України [1]. Впровадження такого підходу дало змогу виокремити індикатори суспільного розвитку, такі як інституціоналізація суб'єктів національної держави в умовах зовнішніх впливів; конституювання механізму делегованого управління: диверсифікація інститутів суспільства, які включені у процес публічно-управлінської діяльності, і не лише у форматі державно-приватного партнерства, а й в інших форматах.

Сучасна проблема раціональності конституційних змін однозначно показує на потребу комплексного реформування публічного управління в Україні. При цьому публічно-управлінська діяльність, що формується на регламентах публічно-правового характеру, в ідеалі завжди має характеризуватися стабільним станом, а реформи у сфері публічного управління мають призводити таку систему до стабільного стану.

Аналіз досліджень і публікацій. Трансформація системи публічного управління в контексті змін до Конституції України була предметом спеціального дослідження таких науковців, як: В. Авер'янов, Г. Атаманчук, В. Бакуменко, В. Баштанник, В. Борденюк, В. Кампо, А. Коваленко, А. Колодій, Н. Липовська, О. Негодченко, Н. Нижник, М. Оніщук, О. Пухкал, С. Серьогін та інші. Важливо вказати на доробки науковців галузі конституційного права, теорії держави і права та політичних наук. Напрями реалізації системних реформ розглянуто в дослідженнях Ю. Друка, М. Клименка, В. Князєва, О. Конотопцева, О. Коротич, Р. Мінченко, М. Ониськіва, А. Пойченка, Л. Приходченко, С. Романюка, В. Тимцуника. При цьому не досить розкритими напрямами наукових досліджень виявились зовнішня зумовленість процесів реформування державного управління в Україні.

Мета статті полягає у розробці теоретико-методологічних засад дослідження конституційних змін в Україні, рекомендацій запровадження таких змін в управлінській практиці на основі запропонованого концепту стабільності управління.

Виклад основного матеріалу. Висхідними засадами нашого дослідження виступають поняття сталості та стабільності, що хоча і $€$ термінами позитивно-публічного змісту.

Сталість в публічному управлінні має близько 200 визначень, і ми пропонуємо у нашому дослідженні певне синтезоване поняття саме 3 позицій публічно-управлінської діяльності. Сталість (іноді вживається термін «стійкість» як синонім, хоча це два різні терміни, якщо брати до уваги теорію систем і системного аналізу) в публічному управлінні - це результуючий стан системи публічного управління на конкретному етапі державотворення, що характеризується здатністю системи до саморозвитку, реалізації владних повноважень, розширення кола активних суб'єктів управління, з єдиною метою - задоволення суспільних потреб на основі визначених законодавством (нормами Конституції і законів України) повноважень відповідних інститутів і суб'єктів управління.

Разом із тим ідеться про усталену управлінську категорію «сталість управління», яку досить часто екстраполюють на більшість управлінських процесів, розуміючи як родове поняття - сталий розвиток (sustainable development). Певною мірою це $\epsilon$ виправданим у концепції державного управління, але після наукового транзиту у площину категорій публічного управління і адміністрування наочною $\epsilon$ необхідність розширення понятійного ряду. Фактично потреба у запровадженні категорії «стабільність публічно-управлінської діяльності» покликана забезпечити інструментальний контент для всієї методологічної сфери науки державного управління.

Справді, на такому етапі розвитку науки державного управління йдеться про новий формат систем публічного управління [2]. В. Баштанник пропонує до наукового обігу категорію «інтегровані системи публічного управління»: «Поняття інтегрованої системи публічного управління 
(ІСПУ) визначається через владу й владні повноваження. Втім узагальнено інтегровану систему публічного управління слід визначити як систему суспільного управління в межах реалізації державних та самоврядних адміністративних повноважень відповідно до Конституції та законів України, яка здатна адаптуватися до змін зовнішнього середовища й, відповідно, змінювати (трансформувати) якісні характеристики елементів системи, а сам процес адаптації визначально забезпечує синергетичний ефект».

В. Баштанник пропонує вести мову не про абсолютно новий тип систем, а характеризує національну надсистему управління, що поєднує діяльність органів влади різних рівнів із необхідним рівнем адміністративної гнучкості, а саме поєднання при цьому забезпечує управлінський результат. Значні переваги впровадження ІСПУ полягають у можливості переходу до принципово нового типу відносин без руйнації ієрархічних зв'язків між рівнями управління. Водночас внутрішні характеристики таких відносин - можливість змінювати в контексті стандартів, правил і процедур, запропонованих як внутрішніми, так і зовнішніми суб'єктами [3]. Ми погоджуємося із цим підходом, проте вважаємо за доцільне доповнити його власним концептом стабільності.

Справді, в межах інтегрованих систем ідеться про стабільність як показник функціонування системи. При цьому дослідники використовують загальновідомий показник стабільності як сукупність параметрів діяльності системи. Ми вважаємо, що стабільність публічно-управлінської діяльності при цьому може мати і власні функціонали стабільності, зокрема, зумовлені властивостями суб'єктів діяльності. Доцільно використати підхід Ф. Рагімова до концептуалізації сталого розвитку, щоб пояснити сутність терміна «стабільність». Так, автор вважає, що інноваційна парадигма виходить із сучасного трактування публічного управління як інтегративного поєднання управлінської діяльності публічних службовців та осіб, що обіймають політичні посади, інституціональної єдності структури і процедур у системі органів державної влади. Публічне управління включає ту діяльність, яка забезпечує ефективне функціонування всієї системи органів державної влади та органів місцевого самоврядування і передбачає широке залучення різних зацікавлених сторін до розробки та реалізації державної політики. Так само Ф. Рагімов вказує на дискусійність сучасного трансформаційного тренду у сфері регіонального управління, зумовленого інституціональною зміною системи регіо- нального управління, дихотомією конституційних норм і положень законопроєктів у сфері регіонального управління, нерозробленістю функціональних регіональних механізмів управління [4].

Такий підхід Ф. Рагімова варто підтримати, проте виникає декілька проблемних напрямів аналізу. По-перше, застосування методології синергетики дозволило представити процес публічного управління у вигляді динамічної моделі альтернативних сценаріїв, яка побудована як дерево ймовірностей. I хоч загалом ми згодні 3 авторським сценарним підходом до розгляду можливостей реформування державного управління сталим розвитком, варто дати відповідь на таке проблемне питання: чи не суперечить динаміка розгортання процесу реформування публічно-управлінської діяльності загалом впровадження інновацій в управлінні у контексті структурування розвитку реформ згідно із життєвим циклом інституційних змін.

Саме тому наш підхід базується на розумінні стабільності як визначального показника здатності публічно-управлінської діяльності до реалізації реформ у разі збереження визначальних параметрів суб'єктів реформування, їх інституціональної визначеності $[5 ; 6]$. На цій основі нами пропонується загальний алгоритм конституційних змін, який заснований на стратегічному розумінні наслідків конституційного реформування, враховує зовнішні чинники впливу на процес реформування, збереження наріжних конституційних принципів, дотримання загальносвітових трендів на пріоритетність забезпечення громадських, політичних, економічних і соціальних прав людини. Базовими засадами конституційних змін слід визначити удосконалення національного законодавства, забезпечення громадсько-політичного схвалення конституційних реформ. Адже раціональний зміст конституційного реформування потребує відповідного юридичного наповнення, трансформації системи органів державної влади та місцевого самоврядування, раціоналізації механізму державно-приватного партнерства, а також політико-ідеологічного наповнення змісту реформування.

При цьому потребує власного методологічного наповнення фрагментованість реформування як особливість національної моделі публічного управління. 3 цією метою слід визначити тенденції конституювання форм і методів публічного управління на наднаціональному, національному, центральному, регіональному та субрегіональному рівнях в умовах конституційних змін, розроблено власну методологічну модель оцінки ефективності конституційного реформування. 
Отже, стабільність публічно-управлінської діяльності - це здатність відкритої системи функціонувати, не змінюючи власну структуру, іманентно властиві характеристики системи та властивості складників системи за якісної зміни суспільних відносин, типу державного правління, зберігаючи стан рівноваги у процесі взаємодії складників системи. У такому разі певні вимоги ми можемо висувати не стільки до самої системи, скільки до характеру конституційного реформування, уточнювати потребу у конституційному змісті власне конституційних реформ, оцінюючи наслідки реформування.

При цьому власне показник стабільності системи у результаті реформ може бути використаний як критерій раціональності реформування. На думку науковців, система та підсистеми органів виконавчої влади мають відповідні організаційні структури, які відображають взаємозв'язки між окремими ланками системи і підсистем, субординацію по вертикалі та горизонталі, стосунки з вищими органами, підпорядкованими і підконтрольними об'єктами. Оптимальність організаційних структур цієї системи $\epsilon$ одним із чинників підвищення ефективності виконавчої влади. Між цими рівнями передбачено субординаційні відносини, й відповідно, системі місцевих органів державної виконавчої влади властиві такі ознаки, як: сукупність взаємопов'язаних, тісно взаємодіючих елементів, відносно самостійних за функціональним принципом; внутрішня організованість системи, що перетворює іiї в єдине цілісне явище зі спільною метою [6].

Варто вказати, що стабільний стан системи публічного управління (відповідно і стабільність публічно-управлінської діяльності) - це такий стан системи, коли незначні інституціональні реформи викликають лише такі самі незначні відхилення системи від базового стану, й при цьому система публічного управління здатна повернутися у початковий стан за деякий час (технічний підхід до аналізу систем). Фактично йдеться про те, що, якщо інституціональний зміст публічноуправлінської діяльності не змінюється істотно у процесі реформ і система публічного управління повертається у природний стан, вектори реформ були вибрані неправильно. Наочним прикладом таких реформ є реформа державного управління і антикорупційна реформа, у межах яких декларувалися зміни парадигми суспільних відносин у визначених сферах, але за період від 2004 по 2021 роки таких змін фактично не відбулося. Адже зміна суб'єктності формування політики, формалізація нових принципів не принесли очікуваних результатів, і фактично спостерігається негативний контекст реформування, коли фундаментальні реформи лише інституційно позиціонували зміст діяльності, а система публічного управління постійно повертається у попередній стан.

У цьому зв'язку слід підкреслити, що універсальність регулятивних механізмів у системі державного управління призводить до узагальненості державно-управлінських рішень у суспільно-політичній сфері на центральному рівні та зниження ефективності управлінських рішень на регіональному та місцевому рівнях [2]. Вирішення такої проблеми, на нашу думку, полягає у концептуальному перегляді основ реформування в Україні на основі розробки алгоритму реформування і цілепокладання реформ на основі суспільних потреб. 3 цією метою варто з'ясувати, за рахунок чого буде досягнута стабільність публічно-управлінської діяльності у процесі реформ, а також на основі яких механізмів управління буде можливість забезпечувати приведення системи до стабільного стану.

Вважаємо за доцільне наголосити на такому стані системи публічного управління, як метастабільність, що характеризується як стан невизначеної (несталої) стабільності. В умовах метастабільності характеристики системи змінюються нелінійно, можемо вести мову про фактичний перехід із одного стабільного стану системи в інший. За цих умов трансформаційна роль публічного управління полягає у забезпеченні стабільності суспільних відносин, без чого неможливо домогтися впорядкованості суспільного життя і постійно підтримувати його в такому стані. Саме у цьому полягає головний зміст управлінської діяльності держави.

Висновки. В умовах конституювання стратегії європейського вектора розвитку України, наближення до європейських стандартів публічного управління спрямованість публічно-управлінської діяльності на забезпечення стабільності потребує чіткого закріплення в нормативних актах органів управління. Інституціональне забезпечення внутрішніх умов для нормального функціонування держави, послаблення протиріч, зумовлених диференціацією суспільства, вимагає розробки принципово нового підходу до стабільного стану системи публічного управління. За таких умов лише стратегічний підхід в управлінні дозволить забезпечити реалізацію конституційних реформ. 


\section{СПИСОК ЛІТЕРАТУРИ:}

1. Конституція України. Прийнята Верховною Радою України 28 червня 1996 року. Відомості Верховної Ради України. 1996. № 30. Ст. 141.

2. Баштанник В. Трансформация административного управления в контексте современных принципов менеджмента. Modern management rewiew. Quarterly, Volume XXI, Research Jornal. № 23 (1/2016). 2016. C. 31-43.

3. Мартиненко В. М. Державне управління: шлях до нової парадигми (теорія та методологія). Харків : Вид-во ХарРІ НАДУ «Магістр». 2003. 218 с.

4. Рагімов Ф. Теоретико-методологічні засади функціонування механізмів державного управління сталим розвитком регіонів в умовах глобалізації. Державне управління та місцеве самоврядування : зб. наук. пр. 2017. Вип. 4. С. 122-129.

5. Баштанник В. Трансформація державного управління в контексті європейських інтеграційних процесів. Дніпро : ДРІДУ НАДУ, 2010. 390 с.

6. Lozytska I. Theoretical and methodological basis of implementation of the foreign experience of administrative regulation in the system of public administration. Development trends in legal science and practice: the experience of countries of Eastern Europe and prospects of Ukraine : monograph. Riga, Latvia : Baltija Publishing, 2018. P. 126-144. 